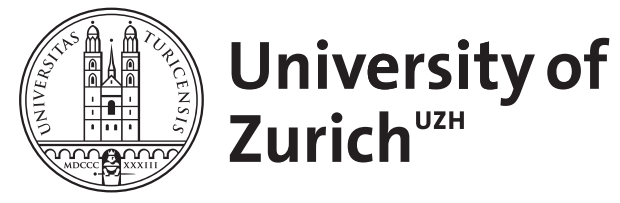

Zurich Open Repository and Archive

University of Zurich

University Library

Strickhofstrasse 39

CH-8057 Zurich

www.zora.uzh.ch

Year: 2021

\title{
in the Odyssey
}

Dunkel, George E

DOI: https://doi.org/10.13109/glot.2021.97.1.83

Posted at the Zurich Open Repository and Archive, University of Zurich ZORA URL: https://doi.org/10.5167/uzh-202823

Journal Article

Accepted Version

Originally published at:

Dunkel, George E (2021). in the Odyssey. Glotta, 97(1):83-88.

DOI: https://doi.org/10.13109/glot.2021.97.1.83 


\title{
'I $\sigma \kappa \varepsilon$ in the Odyssey
}

\author{
By GEORGE DunKel, Zürich
}

1. Liddell/Scott/Jones 1968: 837 differentiates between í $\sigma \kappa \omega \mathrm{A}$ as the

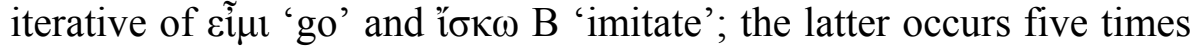
in Homer, twelve times in Apollonius Rhodius, and once each in Simonides, Theocritus, and Lycophron.

Three of the five Homeric occurrences contain the participle

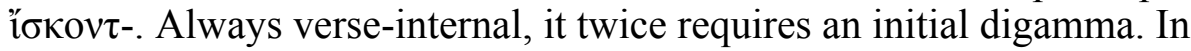
the Odyssey it means 'making (to be) like, imitating' and its object is in the dative:

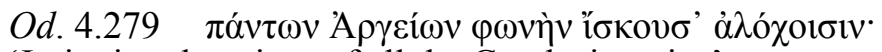

'Imitating the wives of all the Greeks in voice'

In the Iliad it means 'finding similar to':

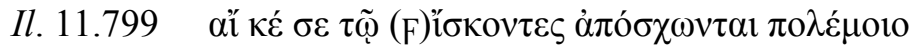

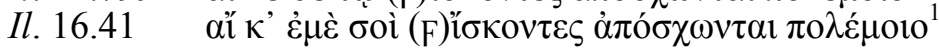

'If, taking you for him (me for you), they will hold off from war'

These meanings are more frequently expressed in Homer by $\dot{\varepsilon} \hat{i} \sigma \kappa \omega$ (fourteen occurrences). Both '̌ $\sigma \kappa \omega$ and हैi $\sigma \kappa \omega$ continue the root *ueik-

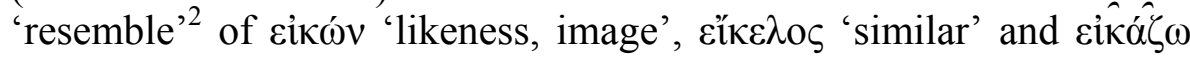
'*make to resemble' > 'portray; compare; conjecture'. The only

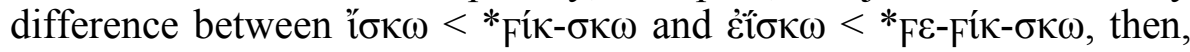
is the initial ${ }_{F} \varepsilon^{-}$-; on its nature see the appendix.

All other occurrences of ' $\sigma \kappa \omega$ are verse-initial; here the assumption of an initial digamma is possible, but gratuitous. Around $500 \mathrm{BC}$ Simonides' epigram LXIX (142 D., on the tomb of a dog) attests a semantic development to 'think or consider (to be); judge that; deem; fancy':

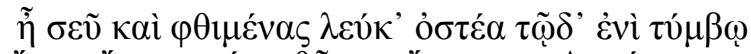

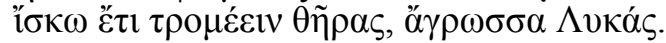

'Although you are dead, oh huntress Lukas, I think the beasts are still trembling at your white bones in this tomb'.

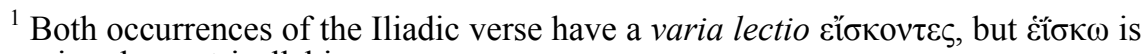
otherwise always trisyllabic.

2 Cf. Lith. pervéikslas 'example', Pokorny 1959 I: 1129. Rix 2001: 670 fn. 4

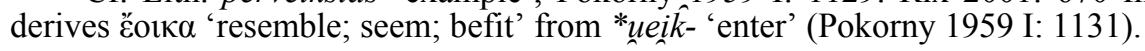

Glotta 97, 83-88, ISSN (Printausgabe): 0017-1298, ISSN (online): 2196-9043

(C) Vandenhoeck \& Ruprecht GmbH \& Co. KG, Göttingen 2021
} 
By the third century BC a different semantic development had

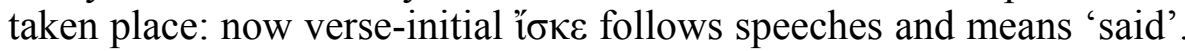
It is found in Alexandrian epic: Apollonius Rhodius, Argonautica 2.240

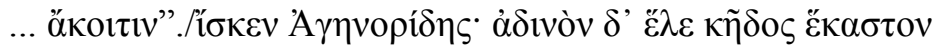

'(So) spoke the son of Agenor, and dense care seized each one' (and eleven times elsewhere), bucolic: Theocritus, Idylls 22.167

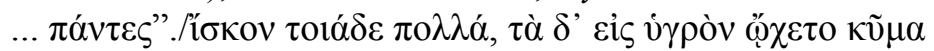

'Such things I told...', and tragedy: Lycophron, Alexandra 573-4

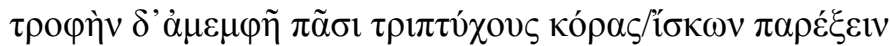

'Saying that his three daughters were going to provide impeccable food for all'.

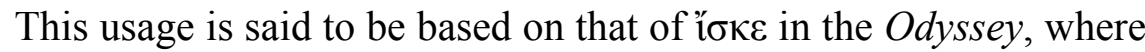
it occurs twice verse-initially following speeches. But both of these passages have posed problems since Alexandrian times.

2. In Odyssey 19.203 the author comments on Odysseus' skill at spinning plausible tales about himself to Penelope:

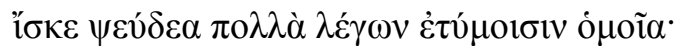

'He knew that he was telling many lies similar to truths'

- or so I have aways understood this verse. To my surprise I seem to be only the second person to have done so; usually ' $\sigma \kappa \varepsilon \varepsilon$ is translated as either 'said, told' or as 'imitated, feigned'. Both interpretations go back to the Alexandrian scholia, themselves summarizing earlier scholarship.

One ancient opinion held that '̌ $\sigma \kappa \varepsilon$ already meant 'said' here as in Alexandrian verse. But here a verbum dicendi is already present in $\lambda \varepsilon \gamma^{\prime} \omega v$. Nonetheless the rendering 'told' is found in Butcher/Lang 1879: 317, Ameis/Hentze 1911: 15 ("rekapitulierend, wie $\tilde{\eta} \dot{\rho} \alpha, \varphi \tilde{\eta}$ ”), and Schadewaldt 1958: 251. Since this meaning is not inherited, ${ }^{3}$ it would have to be the result of one of the already pre-Homeric misunderstandings or re-interpretations of obsolete words of the type studied in detail by M. Leumann 1950.

Other ancient scholars are said to have understood '̌ $\sigma \kappa \varepsilon$ as ó $\mu$ oíov 'made like, imitated' or $\varepsilon$ 'ik $\alpha \zeta \varepsilon$ 'portrayed, represented' as in the above

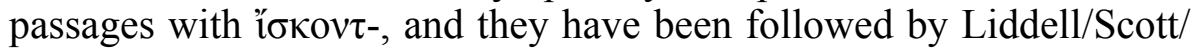

\footnotetext{
${ }^{3}$ The derivation from the root 2. *sek ${ }^{u}$ - 'say' of है $v v \varepsilon \pi \varepsilon$, है $v 1 \sigma \pi \varepsilon \varsigma$, है $\sigma \pi \varepsilon \tau \varepsilon$ and Latin insece, inquit (Pokorny 1959 I: 897-8, Rix 2001: 526-7), as urged most recently by Van der Valk 1949: 116 Fn. 7, is inadmissible, since IE labiovelars

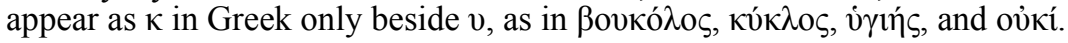


Jones 1968: 837 and Monro 1901: 158; but the object is not in the dative, and 'he imitated lies' just makes no sense here.

The problems with both ancient interpretations were summarized by West 1966: 163: "if ' $\sigma \kappa \varepsilon \varepsilon$ is meant in the proper sense 'assimilate', then o $\mu$ oĩ is superfluous; if it bears the secondary sense 'speak', then $\lambda \varepsilon$ $\gamma \varepsilon ı$ is superfluous". So ไ̌ $\sigma \kappa \varepsilon$ must mean something different from both.

Various modern suggestions must also be rejected. Russo 1992: 87

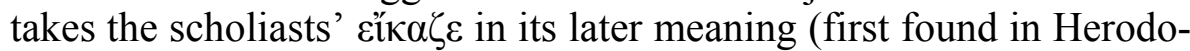
tus) of 'conjecture; guess'; but 'he conjectured lies' is no more satisfactory.

Fernández-Galiano's translation 'he invented lies' (1992: 225) does for once give good sense. However this is not in itself a recommendation: since the meaning 'invent, make up' is found for this verb nowhere else, there is no justification for presuming it here. P. Thieme's methodological warning of "the mistake of complicating the vocabulary in order to simplify the sense" (1957: $55=1984: 726)$, i.e. the danger of multiple ad hoc translations which only serve to disguise the real difficulties of interpretation, holds for Homer as well as for the Rgveda.

Stanford's translation "He made his many falsehoods seem like truth" (1948: 324) ignores both the transmitted verb-forms while verbalizing the adjective 'similar' into a factitive. Even more distant from the text is Fagles 1996: 397: "Falsehoods all, but he gave his falsehoods all the ring of truth".

Unaware that i $\sigma \kappa \varepsilon$ was controversial, due to its radical zero-grade and lack of augment I naïvely understood it as an iterative of oi $\delta \alpha$. Later I came across Hesiod, Theogony 27-8:

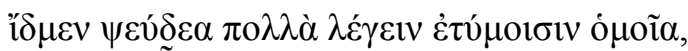

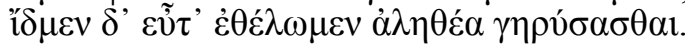

'We know how to tell many lies similar to truths; we also know how, when we want, to voice the truth',

which seemed to confirm my interpretation. But with time I saw that this crucial parallel is not mentioned in any discussion of "̈ $\sigma \kappa \varepsilon$. Its importance was seen only by I. Sellschopp in her effort to show that Hesiod's works are earlier than the Odyssey (1934: 43). ${ }^{4}$ Hesiod's ¿ $\delta \mu \varepsilon v$ is indeed more coherently composed and deployed than

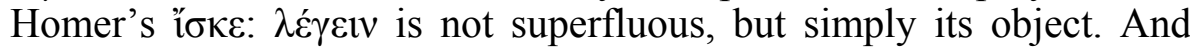

\footnotetext{
${ }^{4}$ Her outdated opinion that '̌ $\sigma \kappa \varepsilon$ originally meant 'said' (see the previous footnote) does not affect her argument, which Edwards 1971: 166-8, 187-9 rejects without offering an alternative interpretation for the Odyssean parallel.
} 
' $\delta \mu \varepsilon v$ itself is bound closely into its context by anaphora and antithetic $\delta \varepsilon$. Finally, $\imath \delta \mu \varepsilon v$ is a non-obvious modification of easily understood as an iterative of " $\delta \mu \varepsilon v$. Admittedly it would be the only known iterative to be built on a perfect stem, though they were occasionally formed to aorists. ${ }^{5}$ But such artificial nonce-creations are after all typical of the Kunstsprache.

I know of only one predecessor for the above translation, Lattimore 1965: 287: "He knew how to say many false things that were like true sayings". But although he interprets "í $\sigma \kappa \varepsilon$ here $^{6}$ in my opinion correctly, Lattimore does not adequately render its syntax. The contrast in object-constructions of verbs of perception between infinitive and participle ${ }^{7}$ means that in contrast to Hesiod's ' $\delta \mu \varepsilon v . . . \lambda \varepsilon$ ' $\gamma \varepsilon ı v$ 'we know how to tell lies similar to truths', Odyssean ǐ $\sigma \kappa \varepsilon$... $\lambda \dot{\varepsilon} \gamma \omega v$ means 'he knew that he was telling lies ...'. That is, Odysseus is here being characterized as a deliberate liar.

3. The other Odyssean occurrence of "̋ $\sigma \kappa \varepsilon$ also follows a speech,

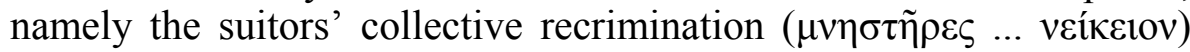
after Odysseus abruptly slaughters Antinoos. The poet comments asyndetically (Odyssey 22.31-3):

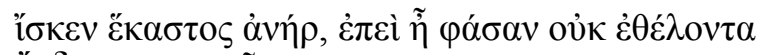

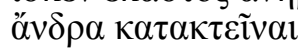

Here the same two Alexandrian interpretations of 'í $\sigma$ Kev have found their modern champions. The meaning 'spoke' found in many of the best translations ${ }^{8}$ would be due to a pre-Homeric metanalysis, Leumann-style. The asyndeton is reminiscent of the frequent expressions for inquit in Homer: $\tilde{\eta}, \varphi \tilde{\eta}$, and $\hat{\iota} \zeta \varphi \alpha ́ \tau o$. Still the usage diverges for no reason from normal Homeric diction which would have fit

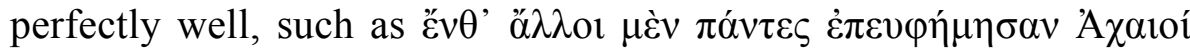

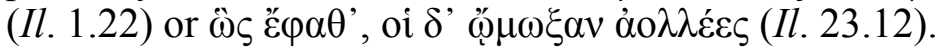

Even more frequent is 'conjectured, guessed; imagined', 9 once again presuming a development from 'make like' to 'guess' parallel to that of $\varepsilon i \kappa a ́ \zeta \omega$ in Herodotus. Problematic is the lack of an adverbial

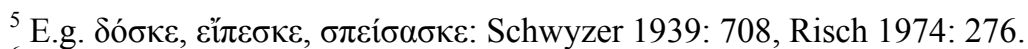

${ }^{6}$ Whereas at $O d .22 .31$ he renders ǐ $\sigma \kappa \varepsilon v$ as 'spoke' (1965: 322).

${ }^{7}$ Schwyzer/Debrunner 1950: 395-6; Smyth 1920: 476.

${ }^{8}$ Butcher/Lang 1879: 360, Ameis/Hentze 1911: 101, Schadewaldt 1958: 284, Lattimore 1965: 322 ("Each spoke at random").

${ }^{9}$ So Liddell/Scott/Jones 1968: 837, Monro 1901: 220, Stanford 1948: 373, Russo 1992: 225-6, Fagles 1996: 440 (“"Each persuading himself”).
} 
'so, likewise,"10 or of an object: 'what had happened' or 'the reason for the shooting'.

Nor does a translation 'each man knew (it)' (from *uid-, as above) make sense. One sympathizes with Aristarchus' athetesis of this passage.

One possibility remains which has never been considered in this context: the original meaning of ' $\sigma \kappa \kappa \nu \tau$ - 'making like, imitating': 'Each man imitated (him/this)', i.e. the others all did the same. The ellipsis of the object (here it would be in the dative) would still be problematic, but the possibility of a translation with a meaning found elsewhere as well is sound philologic practice.

4. In this case not two, but three verbs to $\sigma \omega \omega$ must be differentiated in Homer: one from eĩ $\mu \mathrm{l}$ 'go', one from an earlier fí $\sigma \kappa \omega$ 'imitate', and one hapax legomenon artificially formed to ' $\delta \mu \varepsilon v$ 'know', from IE *uid- 'glance at'.

\section{Appendix: the first syllable of हैit $\sigma \kappa \omega<{ }^{*} F \varepsilon-F \imath \kappa-\sigma \kappa \omega$}

The usual view that $\dot{\varepsilon}^{-},{ }^{*} F \varepsilon$ - is a reduplication ${ }^{11}$ is problematic for two reasons. First, $e$-reduplication in Greek is limited to the perfect and aorist, the few seeming presents being obviously remodeled from those stense-stems, e.g. $\tau \varepsilon \tau \rho \alpha i v \omega$ to $\tau \varepsilon ́ \tau \rho \eta v \alpha$ and $\kappa \varepsilon ́ \kappa \lambda o \mu \alpha \imath$ 'command'

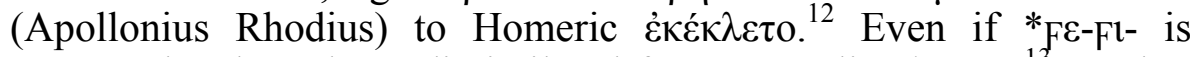
presumed to have been dissimilated from an earlier $* \mathrm{Fl}^{-} \mathrm{Fl}^{-},{ }^{13}$ another difficulty remains: nowhere else in Greek are reduplicated and non-reduplicated presents built from the same root. ${ }^{14}$

For these reasons the first syllable may instead continue the local particle 1.*ue- 'away' (cf. perhaps Mycenaean pejorative we-, see Dunkel 2014 II: 839). A semantic parallel is offered by $\alpha \dot{\pi}-\varepsilon 1 \kappa \alpha ́ \zeta \omega$ 'copy; compare; conjecture, imagine'; after all one copies 'from' or 'off' something. Other seeming reduplications which actually continue

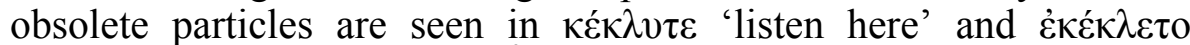
'ordered' with near-deictic *ke (missing in Dunkel 2014 II: 401) and

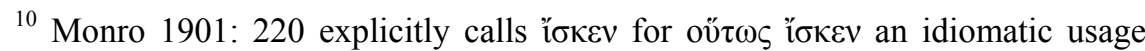
(though it never recurs).

${ }^{11}$ E.g. Liddell/Scott/Jones 1968: 837; Schwyzer 1939: 708; Frisk 1960: 530, 737; Risch 1974: 276.

${ }_{13}^{12}$ Schwyzer 1939: 648.

${ }^{13}$ Due to cacophony according to Schulze 1910: 185 = 1966: 305 ; accepted by Schywzer 1939: 289

${ }^{14}$ Against Epirotic $\gamma \nu \omega ́ \sigma \kappa \omega=\gamma / \gamma \nu \omega ́ \sigma \kappa \omega$ see Forssman 1968: 14-20.
} 
$\pi \iota \varphi \alpha v ́ \sigma \kappa \omega$ 'tell, declare, show' with the zero-grade of غ̇ $\pi$ í (Dunkel 2014 II: 247).

In this case preverb-compound, respectively.

\section{Bibliography}

Ameis, K., and Hentze, C. (1911): Homers Odyssee II.2. Stuttgart.

Butcher, S., and Lang, A. (1879): The Odyssey of Homer. London.

Dunkel, G. (2014): Lexikon der Indogermanischen Partikeln und Pronominalstämme. Heidelberg.

Edwards, M. (1971): The Language of Hesiod. Oxford.

Fagles, R. (1996): The Odyssey. New York.

Fernández-Galiano, M. (1992): A Commentary on Homer's Odyssey III, Books $X X I-X X I I$. Oxford.

Forssman, B. (1968): "Zwei interessante griechische Verbalformen”. MSS 23: 7-20.

Frisk, Hj. (1960): Griechisches etymologisches Wörterbuch I. Heidelberg.

Lattimore, R. (1965): The Odyssey of Homer. Chicago.

Leumann, M. (1950): Homerische Wörter. Basel.

Liddell, H., Scott, R., and Jones, H. (1968): Greek-English Lexicon (9th edn.). Oxford.

Monro, D. (1891): Homer's Odyssey, Books XIII-XXIV. Oxford.

Pokorny, J. (1959): Indogermanisches etymologisches Wörterbuch. Bern.

Risch, E. (1974): Wortbildung der homerischen Sprache (2nd edn.). Berlin.

Rix, H. (ed.) (2001): Lexikon der indogermanischen Verben (2nd edn.). Wiesbaden.

Russo, J. (1992): A Commentary on Homer's Odyssey III, Books XVII-XX. Oxford.

Schadewaldt, W. (1958): Die Odyssee. Hamburg.

Schulze, W. (1910): "Kakophonie". KZ 37: 185-9 = Kleine Schriften (Göttingen 1966): 304-8.

Schwyzer, E. (1939): Griechische Grammatik I. München.

Schwyzer, E., and Debrunner, A. (1950): Griechische Grammatik II. München.

Sellschopp, I. (1934): Stilistische Untersuchungen zu Hesiod. Diss. Hamburg.

Smyth, H. (1920): Greek Grammar. Cambridge.

Stanford, W. (1948): The Odyssey of Homer I. London.

Thieme, P. (1957): "Review of Renou, Études védiques et pāninéennes I". Journal of the American Oriental Society 77: 51-6 = Kleine Schriften (Wiesbaden 1984) I: $722-7$.

Valk, M. van der (1949): Textual Criticism of the Odyssey. Leiden.

West, M. (1966): Hesiod, Theogony. Oxford. 